\title{
Toxicity assessment of four insecticides with different modes of action on pupae and adults of Eriopis connexa (Coleoptera: Coccinellidae), a relevant predator of the Neotropical Region
}

\author{
Marilina Noelia Fogel $^{1,2} \cdot$ Marcela Inés Schneider $^{1,3} \cdot$ Federico Rimoldi $^{2}$. \\ Lorena Sabrina Ladux ${ }^{1} \cdot$ Nicolas Desneux $^{4} \cdot$ Alicia Estela Ronco $^{2}$
}

Received: 21 September 2015 / Accepted: 5 April 2016/Published online: 14 April 2016

(C) Springer-Verlag Berlin Heidelberg 2016

\begin{abstract}
Pesticides can be toxic to nontarget organisms including the natural enemies of agricultural pests, thus reducing the biodiversity of agroecosystems. The lethal and sublethal effects of four insecticides with different modes of actionpyriproxyfen, teflubenzuron, acetamiprid, and cypermethrinwere evaluated on pupae and adults of Eriopis connexa, an effective predator in horticultural crops. Pupal survival was reduced by pyriproxyfen $(26 \%)$ and cypermethrin $(41 \%)$. Malformations in adults emerged from treated pupae were observed after acetamiprid ( 82.7 and $100 \%$ for 100 and $200 \mathrm{mg}$ a.i./l, respectively), pyriproxyfen (48.6\%), and cypermethrin $(13.3 \%)$ treatments. A longer mean oviposition time was also observed in adults emerged from pupae treated with cypermethrin. Moreover, the latter insecticide as well as teflubenzuron did not reduce reproductive parameters, whereas females emerged from pyriproxyfen-treated pupae were not be able to lay eggs even when females showed large abdomens. Upon exposure of adults, survival was reduced to approximately
\end{abstract}

Responsible editor: Markus Hecker

Marcela Inés Schneider

mschneider@cepave.edu.ar

1 Laboratorio de Ecotoxicología: Plaguicidas y Control Biológico, Centro de Estudios Parasitológicos y de Vectores

(CEPAVE-CONICET, Universidad Nacional de La Plata), Boulevard 120 s/n entre 61 y 64, 1900 La Plata, Buenos Aires, Argentina

2 Centro de Investigaciones del Medio Ambiente (CIMA), Facultad de Ciencias Exactas, CONICET, Universidad Nacional de La Plata, Calle 47 y 115, 1900 La Plata, Buenos Aires, Argentina

3 Facultad de Ciencias Naturales y Museo, Universidad Nacional de La Plata, Calle 60 y 122 s/n, 1900 La Plata, Buenos Aires, Argentina

4 French National Institute for Agricultural Research (INRA), UMR-ISA, 400 Route des Chappes, 06903 Sophia-Antipolis, France
$90 \%$ by acetamiprid, but no reduction occurred with pyriproxyfen, teflubenzuron, or cypermethrin though the fecundity at fifth oviposition time of the female survivors was reduced. Pyriproxyfen decreased the hatching at all the oviposition times tested, whereas fertility was reduced in the fourth and fifth ovipositions by teflubenzuron and in the first and third ovipositions by cypermethrin. In conclusion, all four insecticides tested exhibited lethal or sublethal effects, or both, on E. connexa. The neurotoxic insecticides were more harmful than the insect-growth regulators, and pupae were more susceptible than adults. The toxicity of insecticides on the conservation of predators in agroecosystems of the Neotropical Region is discussed.

Keywords Eriopis connexa $\cdot$ Insecticides selectivity $\cdot$ Lethal effects $\cdot$ Sublethal effects

\section{Introduction}

Pesticides have been used in agriculture for the last several decades in order to reduce crop damage by pests although the continuous employment of these chemicals has caused environmental contamination as well as side effects to nontarget organisms. The "Green Revolution" was a period when the productivity of global agriculture increased drastically because of new advances as chemical fertilizers and pesticides, high-yield crops, and multi-cropping system (Sánchez-Bayo 2011). For the last 25 years, however, worldwide trends have been pointing to the search for highly selective pesticides with a low impact on the environment and on human health.

Biological control is an alternative strategy to control pests rather than the use of chemicals. Biological control involves the use of natural enemies (i.e., predators, parasitoids, and entomopathogens) to reduce pest population density below the economic-injury level (Jacas and Urbaneja 2009). It 
represents an environmentally sustainable and economically profitable strategy (Cock et al. 2010). Although the use of pesticides for pest control in the developing countries of South America remains as the principal pest-management strategy (Wyckhuys et al. 2013), biological control through the conservation of beneficial arthropods would constitute an especially useful and relevant tool for maximizing ecosystem services and reducing pesticide use.

Coccinellidae predators have a relevant role in controlling pests, mainly on sap-sucking ones (Weber and Lundgren 2009; Obrycki et al. 2009; Biddinger et al. 2009; Michaud 2012). Within this family, the generalist predator Eriopis connexa (Genmar) is being considered as a potential biocontrol agent for several horticultural crops in the Neotropical Region (Almeida-Sarmento et al. 2007; Duarte Gómez and Zenner de Polanía 2009). In Argentina, this species is commonly found associated with key horticultural pests such as aphids and whiteflies (Fogel 2012). The conservation of $E$. connexa in these agroecosystems is, however, compromised by the indiscriminate application of pesticides, mainly broad-spectrum ones. Therefore, the introduction and application of new reduced risk chemicals are crucial. Indeed, within the pest-control strategies of integrated pest management (IPM), biological and chemical controls by selective pesticides are both worldwide promoted nowadays (Desneux et al. 2007; Stark et al. 2007; Yao et al. 2015).

Pyriproxyfen, teflubenzuron, and acetamiprid insecticides are commonly used on Argentine horticultural crops for controlling phytophagous pests and considered as selective insecticides due to having a lower environmental impact than conventional insecticides (EPA 2013). Although their effectiveness on several pests has been widely documented (Ishaaya et al. 1994; Ishaaya et al. 2001; Bacci et al. 2007), few studies are yet available indicating their potential toxicity to nontarget organisms, such as coccinellids.

Pyriproxyfen is a potent juvenile-hormone analog mimicking the authentic hormonesecreted by the Corpus allatum in insects that causes strong suppression of embryogenesis, metamorphosis, and adult formation (Ghanim and Ishaaya 2010). Teflubenzuron, belonging to the group of benzoylureas, has insecticidal action on larvae through an inhibition of chitin synthesis that causes cuticle rupture and consequent death (Ware and Whitacre 2004). Acetamiprid is a neonicotinoid that antagonizes the central nervous systems of insects through a specific interaction with nicotinic acetylcholine receptors to produce excitation, paralysis, and death (Tomizawa and Casida 2005).

Pyriproxyfen, teflubenzuron, and acetamiprid have been considered harmless to several natural enemies of agricultural pests and, thus, are compatible with IPM programs (Ishaaya et al. 2007; Moscardini et al. 2013). A worldwide controversy exists, however, as to the selectivity of neonicotinoids, such as acetamiprid, because of the high toxicity documented for several pollinators along with certain other beneficial insects (Grafton-Cardwell and Gu 2003; Papachristos and Milonas 2008; Blacquiêre et al. 2012; He et al. 2012; Fogel et al. 2013; Malagnoux et al. 2015). Moreover, neonicotinoid insecticides are frequently detected in soil and water and are also found in air, as dust particles during sowing of crops and aerosols during spraying (Chagnon et al. 2015).

Other conventional insecticides such as pyrethroids have been found to be harmful to several vertebrates such as amphibians and fish (Singh and Singh 2008; Agostini et al. 2010) along with arthropods (Desneux et al. 2004a; Schneider et al. 2006; Rimoldi et al. 2008, 2012; Benamú et al. 2013), but those products nevertheless still remain on the market. Cypermethrin, for example, has been widely used in agroecosystems in Argentina under open field and greenhouse conditions for several years, and it has not yet been replaced by environmentally friendly compounds mainly because of the high cost of biorational pesticides (Cappello and Fortunato 2008). This insecticide acts at the level of the central nervous system on axonic $\mathrm{Na}^{+}$channels, producing an excessive input of the ion that leads to a continuous excitation of the axonic membrane, causing repetitive discharges and eventual paralysis (Stenersen 2004).

Within this context, the aim of the present study was to evaluate, under laboratory conditions, the toxicity of pyriproxyfen, teflubenzuron, acetamiprid, and cypermethrin on the pupal and adult stages of the predator E. connexa according to the criteria of modern ecotoxicology, where the lethal and sublethal effects are considered equally relevant (Desneux et al. 2007; Stark et al. 2007).

\section{Materials and methods}

The insect colonies and bioassays were carried out in a growth chamber with controlled environmental conditions: temperature, $25 \pm 2{ }^{\circ} \mathrm{C}$; relative humidity, $70 \pm 5 \%$; and photoperiod, 16:8-h (light/dark).

\section{Insects}

Eriopis connexa adults used to establish a colony in the laboratory were obtained from surveys carried out on horticultural crops within the environs of La Plata, Argentina (34 $57^{\circ} 17^{\prime \prime}$ S, $\left.57^{\circ} 53^{\prime} 26^{\prime \prime} \mathrm{W}\right)$. The bird-cherry aphid Rhopalosiphum padi (Linnaeus, 1758; Hemiptera: Aphididae) was used as prey, and a colony was initiated from clones obtained from the School of Agricultural and Forestry Sciences (National University of La Plata, Argentina) with the individuals being reared on pesticide-free wheat seedlings (Triticum aestivum L.; cultivar ACA 901). E. connexa adults used for testing were fed ad libitum with prey and an artificial diet based on a beefliver nutritional supplement (Martos and Niemeyer 1990). 


\section{Insecticides}

The formulated insecticides tested were Epingle ${ }^{\circledR}(10 \%$ $[w / v]$ pyriproxyfen; Summit-Agro, Buenos Aires, Argentina), Nomolt ${ }^{\circledR}(15 \%[w / v]$ teflubenzuron; BASF, Buenos Aires, Argentina), Mospilan ${ }^{\circledR}$ (acetamiprid $20 \%[w / w]$; Summit-Agro, Buenos Aires, Argentina), and Glextrin $25^{\circledR}(25 \%[w / v]$ cypermethrin; Gleba, La Plata, Argentina). For each insecticide, the following maximum recommended field concentrations (MRFCs) registered in Argentina (CASAFE 2013/2015) were assessed: pyriproxyfen, $75 \mathrm{mg}$ of active ingredient (a.i.) $\mathrm{L}^{-1}$; teflubenzuron, $45 \mathrm{mg}$ a.i. $\mathrm{L}^{-1}$; acetamiprid, $200 \mathrm{mg}$ a.i. $\mathrm{L}^{-1}$; and cypermethrin, $25 \mathrm{mg}$ a.i. $\mathrm{L}^{-1}$. For the pupal bioassay, the $50 \% \operatorname{MRFC}\left(100 \mathrm{mg}\right.$ a.i. $\left.\mathrm{L}^{-1}\right)$ of acetamiprid was also evaluated, based on the results of a previous study for immature stages (eggs, second and fourth larval instars) indicating MRFC to be highly toxic to predators (Fogel et al. 2013).

\section{Bioassays}

\section{Pupae bioassay}

Three replicates of ten young pupae each (at fewer than $24 \mathrm{~h}$ after pupation) from the laboratory colony were used in each treatment. Each individual was exposed to $1 \mu$ l of insecticide by topical application with a hand microapplicator $\left(\right.$ Burkard $\left.^{\circledR}, \mathrm{UK}\right)$. Insecticide solutions were prepared in acetone (analytical grade) as the solvent. For acetamiprid, the solutions were prepared with $20 \%(v / v)$ acetone in distilled water (Youn et al. 2003) for improving dissolution. Controls were treated with the solvent alone.

The weight of the pupae averaged $0.43 \pm 0.07 \mathrm{~g}$, so that the concentrations studied were equivalent to doses in micrograms a.i. per gram pupae of 0.17 for pyriproxyfen, 0.10 for teflubenzuron, 0.06 for cypermethrin, and 0.46 and 0.23 for acetamiprid at 100 and $50 \%$ of the MRFC, respectively. The treated pupae were placed individually in plastic Petri dishes (9-cm diameter, $1.5-\mathrm{cm}$ height) and then transferred to a growth chamber under the environmental conditions mentioned above. The following end points were evaluated daily: pupal survival (pupae with dark coloration being considered dead) and abnormal morphology in the emerged adults (i.e., malformations and abnormalities). In treatments where normal females were observed, we also measured the mean oviposition time (mean time after adult emergence and the first egg laying), cumulative fecundity (number of eggs laid), and fertility (percentage of eggs hatched) during the first $48 \mathrm{~h}$ after the first oviposition (according to a prior pilot bioassay).
Adult bioassay

Before exposure, five groups of $30 \mathrm{E}$. connexa adults (5-dayold; sex ratio $0.5: 0.5)$ from the laboratory colony were placed in cylindrical plastic containers $(18-\mathrm{cm}$ diameter, $15-\mathrm{cm}$ height) for 5 days to insure the effective mating of the females. Next, the adults were separated into individual ventilated plastic containers (5-cm diameter, 7-cm height) and exposed to doses of each product in drinking water at the MRFCs indicated above. The solutions were changed daily for 3 days (Viñuela et al. 2001), after which time the individuals were provided with distilled water. Each treatment consisted of three replications of 10 adults. For a total of 15 days, we assessed the survival of the adults and the reproductive capacity of the females daily. From this, the adult cumulative survival at the end of the bioassay was determined, and the mean oviposition time and the fecundity and fertility of the females during the first five ovipositions (that normally occurred during the first 15 days from adult emergence) were recorded. The reproductive parameters were evaluated in the treatments where more than 12 females survived (the minimum number for statistical validity).

\section{Statistical analysis}

Results are presented as the means \pm standard error. Before data analysis, the Shapiro-Wilk test was used to assess data normality. One-way analysis of variance (ANOVA) or the repeated-measures ANOVA test was used to ascertain differences between treatments. When necessary, a log-data transformation $\left[y=\log _{10}(x+1)\right]$ or an angular transformation $\left(p^{\prime}\right.$ $=\operatorname{arcsine} p^{1 / 2}$ ) were done (Zar 1996). After ANOVA, the separation of the means was assessed by a multiple-range test (LSD; $P<0.05$ ). Survival analysis was used to determine the mean oviposition time with each treatment. The survival functions were estimated by the Kaplan-Meier method along with the Log-rank test for treatment comparisons, through the use of the Bonferroni correction for paired comparisons between treatments. The XLStat program (Addinsoft XLstat for Excel, Paris, France. 2009. http://xlstat.softonic.com) was used in the analyses.

\section{Results}

\section{Pupae bioassay}

The conventional insecticide cypermethrin produced the highest toxicity among the pesticides tested, reducing the survival of the pupae by $41 \%$. The biorational insecticide pyriproxyfen also significantly diminished pupal survival by $26 \%$ (Table 1). Neither of the other insecticides caused a significant degree of pupal mortality. 
Table 1 Side effects of pyriproxyfen, teflubenzuron, cypermethrin, and acetamiprid on the survival and teratology of Eriopis connexa from the topical bioassay on the pupal stage

\begin{tabular}{lllr}
\hline Treatments & $\begin{array}{l}\text { Concentration } \\
\left(\text { mg a.i. L } L^{-1}\right)\end{array}$ & $\begin{array}{l}\text { Survival } \\
\text { pupae (\%) }\end{array}$ & \multicolumn{1}{c}{$\begin{array}{l}\text { Adults } \\
\text { malformed }\end{array}$} \\
\hline Control & 0 & $100 \pm 0.0 \mathrm{a}$ & $0 \pm 0.0 \mathrm{a}$ \\
Pyriproxyfen & $75^{\mathrm{a}}$ & $74.0 \pm 7.4 \mathrm{bc}$ & $48.6 \pm 8.4 \mathrm{~b}$ \\
Teflubenzuron & $45^{\mathrm{a}}$ & $81.5 \pm 7.4 \mathrm{ab}$ & $0 \pm 0.0 \mathrm{a}$ \\
Cypermethrin & $25^{\mathrm{a}}$ & $59.2 \pm 3.7 \mathrm{c}$ & $13.3 \pm 6.6 \mathrm{a}$ \\
Acetamiprid & $200^{\mathrm{a}}$ & $85.2 \pm 9.7 \mathrm{ab}$ & $100 \pm 0.0 \mathrm{c}$ \\
Acetamiprid & 100 & $95.8 \pm 4.1 \mathrm{a}$ & $82.7 \pm 10.5 \mathrm{c}$ \\
\hline
\end{tabular}

The data correspond to means $( \pm \mathrm{SE})$. Different letters within columns denotes significant differences between treatments. One-way ANOVA $(p \leq 0.05)$. Surviving pupae: $F=5.59 ; d f=5,17 ; P \leq 0.007$. Malformed adults: $F=43.3, d f=5,17, P \leq 0.0001$

${ }^{a}$ Maximum recommended field concentration

${ }^{\mathrm{b}}$ Percentage of total adults malformed

Acetamiprid, pyriproxyfen, and cypermethrin caused malformations in adults emerged from treated pupae. In detail, 100 and $82 \%$ of the adults emerging from pupae treated with acetamiprid at the MRFC and $50 \%$ of the MRFC, respectively, exhibited malformations, whereas 49 and $13 \%$ of adults emerging from pupae treated by pyriproxyfen and cypermethrin showed malformations, respectively. In contrast, no malformed adults emerged after pupae exposure to the MRFC of teflubenzuron (Table 1).

Acetamiprid (at 100 and $50 \%$ of the MRFC) and pyriproxyfen (at the MRFC) caused similar severe malformations on individuals after pupal exposure. In acetamiprid treatments, diverse types of malformations involving intermediate stages of development were observed-i.e., organisms with their anterior part consisting of an adult head, but having the thorax and abdomen of a pupa (Fig. 1b). Other individuals manifested partially developed elytra that adhered to the rest of pupal cuticle or individuals that exhibited smaller elytra that did not cover their thorax and abdomen (Fig. 1c, d). Pyriproxyfen also disrupted normal metamorphosis (from pupa to adult), observing intermediate stages of development and some adults emerged malformedi.e., having divided elytra with an inability to discard the remains of the puparium: Fig. 1e, f).

Effects on the reproductive parameters of adults could be assessed only when enough normal adults (without malformation) were recovered. Although the assessment in adults emerging after pupal acetamiprid treatment was therefore impossible, the evaluation could be performed for the other insecticides assayed (Table 1). Accordingly, the organisms exposed to cypermethrin had higher mean oviposition times than the controls in the form of a delay in the time to the first oviposition. Nevertheless, no effect was observed on the cumulative fecundity and fertility at $48 \mathrm{~h}$ (Table 2 ). Teflubenzuron, however, affected neither the mean oviposition times nor the cumulative fecundity and fertility (Table 2). Although $50 \%$ of the pupae treated with pyriproxyfen developed into anatomically normal adults, the females failed to lay eggs in spite of the development of their ovaries, as assessed on the basis of their notably large abdomens (Table 2).

\section{Adults bioassay}

Acetamiprid significantly reduced the cumulative survival of the E. connexa adults (Fig. 2) with the shortest time to causing effects (all organisms dead $24 \mathrm{~h}$ after exposure), whereas pyriproxyfen, teflubenzuron, and cypermethrin caused no significant change in survival, thus enabling an evaluation of the subsequent effects on reproductive parameters. None of the insecticides tested affected the mean oviposition time (log rank $=3.174, d f=3, P=0.366$ ), while the effects on the fecundity and fertility were dissimilar. The adults exposed to pyriproxyfen and cypermethrin laid more eggs during the first oviposition than the controls. While in the fifth oviposition, the fecundity declined significantly. Teflubenzuron reduced the fecundity in only the fifth oviposition, whereas the fecundity in the other ovipositions was similar to that of the controls (Table 3). A reduction in the egg hatches (fertility) was detected after treatment with pyriproxyfen in all of the ovipositions, while lower percentages of hatching were also observed in the first and third oviposition of the adults exposed to cypermethrin. Teflubenzuron, however, produced significant effects on fertility in only the third oviposition (Table 3).

\section{Discussion}

Agro-ecosystems are continuously exposed to pesticides through pest management by farmers, which is a practice that contributes to a loss in the biodiversity within these environments (Gibbs et al. 2009), reducing the population density of nontarget organisms, as species that feed on phytophagous pests.

The biological control of pests by natural enemies has a low environmental impact, and it has been promoted in conjunction with their use of selective pesticides in IPM programs to enhance the biodiversity of agricultural ecosystems. In the past few decades, however, many studies have reported either negative or lethal and/or sublethal effects of pesticides on beneficial nontarget organisms including natural enemies of agricultural pests (Schneider et al. 2003, 2004, 2006; Desneux et al. 2007; Ronco et al. 2008; Biondi et al. 2012; Benamú et al. 2013). Nevertheless, the side effects of pesticides on Coccinellidae predators have not been deeply documented yet.

The present study contributes with novel ecotoxicological data of a neonicotinoid, acetamiprid; a pyrethroid, 

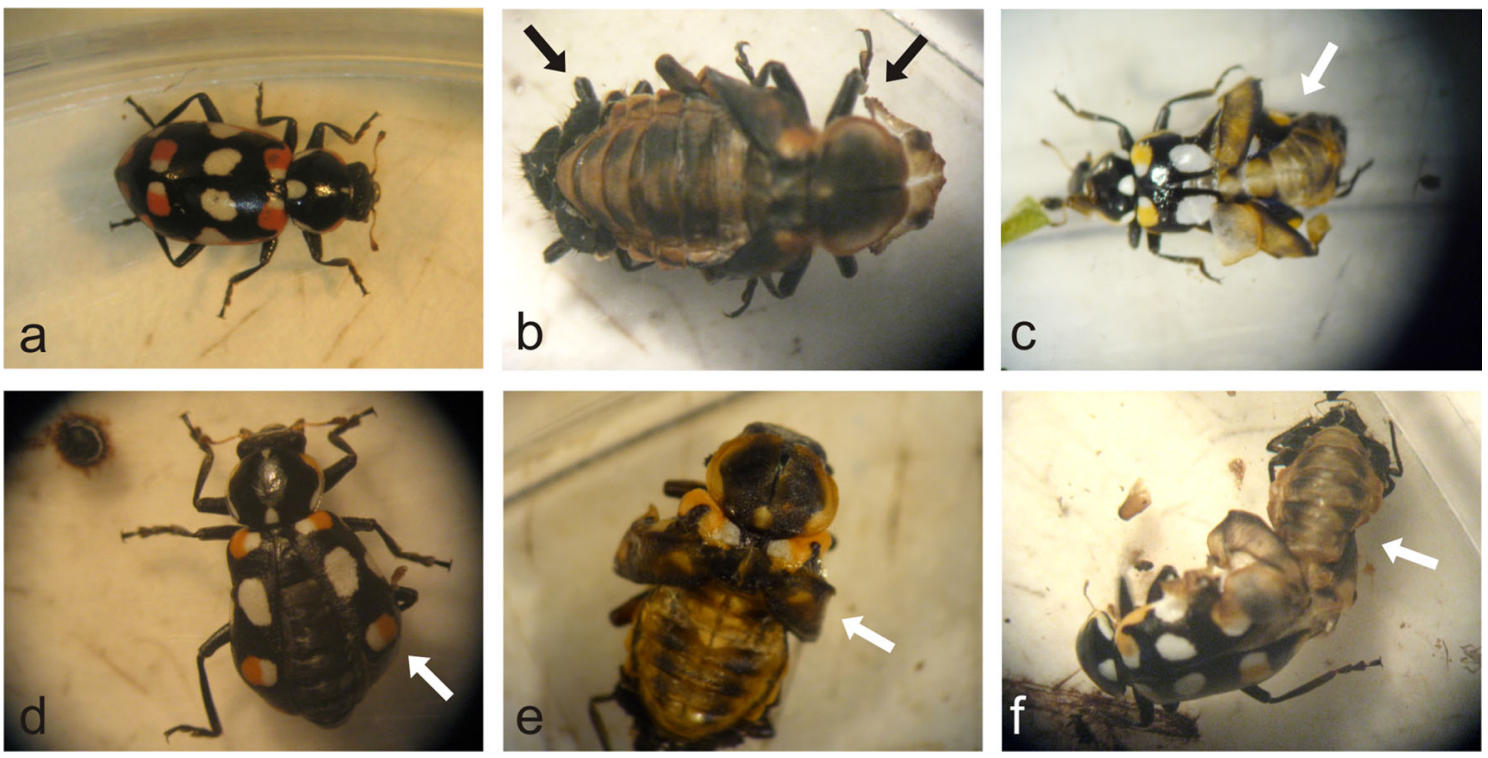

Fig. 1 Malformations in Eriopis connexa after topical exposure of pupae. a Control adult, b, c acetamiprid (200 mg L $\mathrm{m}^{-1}$ a.i.), d acetamiprid (100 mg L ${ }^{-1}$ a.i.), e, f pyriproxyfen ( $75 \mathrm{mg} \mathrm{L}^{-1}$ a.i.). Arrows signalize the main malformations observed

cypermethrin, and two IGR insecticides, pyriproxyfen, and teflubenzuron, on the coccinellid E. connexa. All insecticides affected several biological parameters of predator but to our knowledge, this is the first report on neurotoxicans insecticides acetamiprid and cypermethrin to cause malformations and impair metamorphic processes in pupae of $E$. connexa.

\section{Effects of insecticides on pupae}

In the present study, pyriproxyfen caused adverse effects on the treated pupae of E. connexa that affected pupal survival. These results agree with those from other reports on various natural enemies of pests (Chen and Liu 2002; Schneider et al.

Table 2 Effect of pyriproxyfen, teflubenzuron, and cypermethrin on the reproductive parameters of Eriopis connexa adult survivors from the topical bioassay on the pupal stage

\begin{tabular}{lllll}
\hline & $\begin{array}{l}\text { Concentration } \\
\left(\mathrm{mg} \mathrm{a.i.} \mathrm{L}^{-1}\right)\end{array}$ & $\begin{array}{l}\text { Mean } \\
\text { oviposition } \\
\text { time (days) }\end{array}$ & $\begin{array}{l}\text { Cumulative } \\
\text { fecundity }^{\mathrm{a}}\end{array}$ & $\begin{array}{l}\text { Cumulative } \\
\text { fertility }^{\mathrm{b}}\end{array}$ \\
\hline Control & 0 & $6.6 \pm 0.1 \mathrm{a}$ & $36.7 \pm 3.8 \mathrm{a}$ & $85.1 \pm 4.6 \mathrm{a}$ \\
Pyriproxyfen & 75 & - & $0 \pm 0.0 \mathrm{~b}$ & - \\
Teflubenzuron & 45 & $7.1 \pm 0.3 \mathrm{a}$ & $28.4 \pm 5.9 \mathrm{a}$ & $70.3 \pm 9.1 \mathrm{a}$ \\
Cypermethrin & 25 & $8.4 \pm 0.4 \mathrm{~b}$ & $35.5 \pm 6.7 \mathrm{a}$ & $\begin{array}{c}75.5 \pm 11.9 \\
\mathrm{a}\end{array}$ \\
& & & & \\
\hline
\end{tabular}

The data correspond to means ( $\pm \mathrm{SE}$ ). Different letters within columns denote significant differences between treatments; $P \leq 0.05$. Mean oviposition time: $d f=2, P \leq 0.04$, long rank $=6.423$. Cumulative fecundity: $F=16.77 ; d f=3,26 ; P \leq 0.0001$. Cumulative fertility: $F=1.25 ; d f=2$, $19 ; P=0.311$. One-way ANOVA $(P=0.05)$

${ }^{a}$ Fecundity: Mean number of eggs laid/female

${ }^{b}$ Fertility: Percentage of eggs hatched/female
2004; Planes et al. 2013). Furthermore, we also recorded malformations and/or other abnormalities in the emerged adults. Malformed organisms associated with pyriproxyfen exposure have been reported in various beneficial arthropods-e.g., Rodolia cardinalis Mulsant (Mendel et al. 1994), Podisus maculiventris Say (Mestdagh et al. 1996), and Encarsia formosa Gahan (Darvas and Polgar 1998).As for reproductive parameters, we observed that females of E. connexa, though exhibiting large abdomens, were unable to lay eggs during the assessment period so that the mean oviposition time with those adults could not be measured. Pyriproxyfen is known to mimic the action of the juvenile hormone during the immature stages of insects to induce disruptions during metamorphosis, suppress embryogenesis, and stunt and modify adult formation (Ishaaya et al. 1994). We therefore expected to observe malformations in the pupal stage and ostensibly normal female adults not capable of laying eggs (fecundity inhibition).

Although the neonicotinoid central nervous system antagonist acetamiprid did not cause mortality after pupal exposure, malformations occurred during metamorphosis. On the basis of our results, the observed malformations during metamorphosis could be explained upon consideration that the central nervous system regulates the synthesis of neurohormones that, in turn, control different enzymatic processes, whose actions finally determine the degree of growth and the extent and nature of developmental hormone production. Several authors have reported sublethal effects of neonicotinoids on the natural enemies of pests - such as an immobility of predator Deraeocoris brevis (Uhler) (Kim et al. 2006), neurotoxic symptoms such as tremors, paralysis, and loss of coordination on the predator coccinellid Hippodamia undecimnotata 


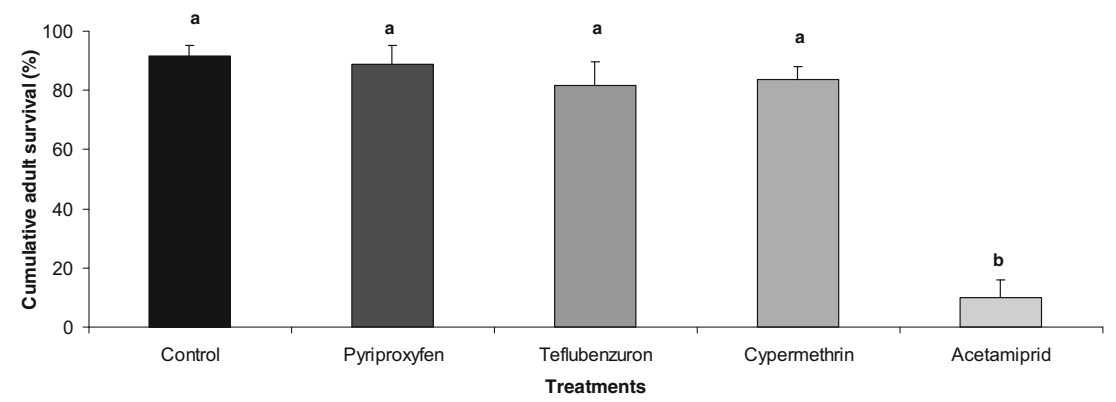

Fig. 2 Effect of pyriproxyfen, teflubenzuron, cypermethrin, and acetamiprid on the cumulative survival (15 days) of Eriopis connexa after adult treatments by ingestion (through the drinking water). Data

(Schneider) (Papachristos and Milonas 2008), a shortening of the developmental period on ladybird beetle, Coccinella septempunctata L. (Yu et al. 2014), and a decrease in the rate of food consumption of predator Serangium japonicum Chapin (He et al. 2012). However, malformations as sublethal effects of this insecticide have been not reported yet, and the present report constitutes the first documentation of malformations of a neonicotinoid insecticide on $E$. connexa that indicate either a direct or an indirect effect on metamorphosis, though the mechanisms involved have yet to be elucidated.

The pyrethroid cypermethrin produced significant effects on the survival of E. connexa pupae. Our results agree with studies from several investigators reporting reduced larval stages and pupal survival in other natural enemies after exposure to this insecticide (Lorca Gonzalez 2005; Rimoldi et al. 2008; Garzon et al. 2015). With cypermethrin-treated pupae, correspond to means $( \pm \mathrm{SE})$. Treatments with different letters are significantly different (one-way ANOVA $P<0.05$ ) at $F=38.3$, $d f=4,15, P \leq 0.0001$

although the fecundity and fertility upon reaching the adult stage were not affected, the mean oviposition time was delayed. Similar results had been obtained with cypermethrin on the predators Chrysoperla externa Hagen and P. maculiventris (Mohaghegh et al. 2000; Rimoldi et al. 2012).

No effects were observed on the survival of the pupae, the morphology of the emerged adults, or the reproductive parameters of $E$. connexa after pupal exposure to teflubenzuron. The lack of toxicity of this insecticide and other chitin inhibitors has been extensively documented for other arthropod predators: Chrysoperla carnea Stephens (Medina et al. 2003), Harmonia axyridis Pallas (James 2004), and the parasitoids Aphytis melinus DeBach (Rill et al. 2008) and Encyrtus infelix Embleton (Mendel et al. 1994). Schneider et al. (2003), however, reported a reduction in reproductive parameters of another parasitoid species Hyposoter didymator Thunberg upon pupal exposure to the chitin-synthesis inhibitor diflubenzuron.

Table 3 Effect of pyriproxyfen, teflubenzuron, and cypermethrin on reproductive parameters of Eriopis connexa from bioassay on the adult stage

\begin{tabular}{|c|c|c|c|c|c|c|}
\hline & $\begin{array}{l}\text { Concentration } \\
\left(\mathrm{mg} \text { a.i. } \mathrm{L}^{-1}\right)\end{array}$ & First oviposition & Second oviposition & Third oviposition & Fourth oviposition & Fifth oviposition \\
\hline \multicolumn{7}{|c|}{ Fecundity $^{\mathrm{a}}$} \\
\hline Control & 0 & $17.2 \pm 1.4 \mathrm{a}$ & $16.7 \pm 1.4 \mathrm{a}$ & $15.0 \pm 1.6 \mathrm{a}$ & $17.0 \pm 2.6 \mathrm{a}$ & $25.1 \pm 3.7 \mathrm{a}$ \\
\hline Pyriproxyfen & 75 & $20.6 \pm 3.6 b$ & $17.6 \pm 4.1 \mathrm{a}$ & $17.8 \pm 3.1 \mathrm{ab}$ & $13.0 \pm 4.1 \mathrm{a}$ & $12.0 \pm 4.0 \mathrm{~b}$ \\
\hline & 45 & $18.6 \pm 4.4 \mathrm{a}$ & $19.0 \pm 3.0 \mathrm{a}$ & $18.6 \pm 1.3 \mathrm{ab}$ & $16.9 \pm 3.1 \mathrm{a}$ & $12.1 \pm 4.7 b$ \\
\hline $\begin{array}{l}\text { Teflubenzu- } \\
\text { ron }\end{array}$ & & & & & & \\
\hline Cypermethrin & 25 & $22.32 .3 b$ & $14.9 \pm 2.6 \mathrm{a}$ & $12.0 \pm 1.7 b c$ & $16.8 \pm 2.8 \mathrm{a}$ & $10.6 \pm 2.5 b$ \\
\hline \multicolumn{7}{|c|}{ Fertility $^{\mathrm{b}}$} \\
\hline Control & 0 & $61.8 \pm 7.3 \mathrm{a}$ & $70.2 \pm 5.1 \mathrm{a}$ & $80.9 \pm 4.9 \mathrm{a}$ & $68.2 \pm 6.7 \mathrm{a}$ & $60.9 \pm 7.4 \mathrm{a}$ \\
\hline Pyriproxyfen & 75 & $42.3 \pm 8.9 \mathrm{c}$ & $41,8 \pm 8.0 \mathrm{~b}$ & $50.0 \pm 10 \mathrm{c}$ & $48,7 \pm 9.1 b$ & $48,9 \pm 9.0 \mathrm{~b}$ \\
\hline & 45 & $62.7 \pm 10.5 \mathrm{a}$ & $63.0 \pm 8.7 \mathrm{a}$ & $62.6 \pm 7.2 \mathrm{~b}$ & $54.7 \pm 12.7 \mathrm{~b}$ & $63.5 \pm 12.7 \mathrm{a}$ \\
\hline \multicolumn{7}{|l|}{$\begin{array}{l}\text { Teflubenzu- } \\
\text { ron }\end{array}$} \\
\hline Cypermethrin & 25 & $72.2 \pm 7.1 \mathrm{~b}$ & $63.1 \pm 9.1 \mathrm{a}$ & $66.9 \pm 5.8 b$ & $66.1 \pm 5.8 \mathrm{a}$ & $62.9 \pm 7.4 \mathrm{a}$ \\
\hline
\end{tabular}

The data correspond to means $( \pm \mathrm{SE})$. Treatments with different letters within columns are significantly different. Repeated measures ANOVA $(P \leq 0.05)$. Fecundity: $F=1.502 ; d f=19,235 ; P \leq 0.086$. Fertility: $F=1.724, d f=19,215, P \leq 0.034$

${ }^{a}$ Fecundity: Mean number of eggs laid/female

${ }^{b}$ Fertility: percentage of eggs hatched/female 


\section{Effects of insecticides on adults}

Acetamiprid caused a significant increase in mortality of E. connexa adults after ingestion via drinking water. Several studies with acetamiprid and other neonicotinoids had observed similar effects on several Coccinellidae species such as H. axyridis (Youn et al. 2003; Moser and Obrycki 2009), $R$. cardinalis (Grafton-Cardwell and Gu 2003), Serangium japonicum Chapin (He et al. 2012), and H. undecimnotata (Papachristos and Milonas 2008). The present results corroborate those of prior studies with eggs and larvae of this predator and confirmed the effects of this pesticide on all development stages of E. connexa (Fogel et al. 2013).

In the present study, pyriproxyfen and teflubenzuron did not affect the survival of E. connexa adults; however, the negative impact on reproductive parameters, though the effects by teflubenzuron were significantly lower. Liu and Stansly (2004) had observed deleterious effects on the fertility of Delphastus catalinae Horn in adults fed with pyriproxyfentreated whitefly eggs. Nevertheless, this insecticide was harmless to adults of $R$. cardinalis after exposure via ingestion, though this insecticide reduced the number of progeny (Grafton-Cardwell and Gu 2003).

After oral ingestion, cypermethrin did not affect the survival of E. connexa adults. By contrast, several studies had reported toxicity of pyrethroids in adult predators and parasitoids (Grafton-Cardwell and Gu 2003; Desneux et al. 2004b; Rimoldi et al. 2012). This discrepancy between our and other studies could be attributed to the well-known repellent effect of pyrethroids on arthropods; accordingly, the absence of toxicity, in fact, could have resulted from an actual low exposure to the active ingredient (Desneux et al. 2005; Benamú et al. 2013). On the other hand, this insecticide drastically reduced fecundity and fertility of E. connexa, agreeing with studies reported by Rimoldi et al. (2012), who observed a decrease in the fertility of the adult $C$. externa.

\section{Insecticides and IPM programs}

The pest control strategies of the IPM paradigm include chemical intervention by selective pesticides and alleges compatibility between the pest-regulatory strategies employed (i.e., biological and chemical control). The lethal and sublethal effects observed in this study on the predator E. connexa become highly relevant to this criterion of compatibility and must be taken into account when considering strategies for conserving this species as a potential biological-control agent in horticultural crops of the Neotropical Region.

In conclusion, taking into account the results obtained on both development stages of the test species and considering the framework of the IPM paradigm, acetamiprid caused both lethal and sublethal effects, whereas pyriproxyfen and cypermethrin mainly induced sublethal effects.
Teflubenzuron was the less toxic tested insecticide toward $E$. connexa. The results reported here highlight the relevance of these insecticide effects not only on the directly exposed organisms but also on their progeny, causing a reduction in the size of it that could impact on the predator population dynamics and conservation of it in agroecosystems.

Regarding the high toxicity and sublethal effects of the neonicotionid acetamiprid on E. connexa, it is recommended that this insecticide should not be included in IPM programs involving this predator as biocontrol agent.

Acknowledgments This research was funded by a PICT 2010-0891and PICT 2011-1752-BID projects from the Argentine National Agency for the Promotion of Science and Technology (ANPCyT-FONCyT) granted to Alicia Ronco and Marcela I. Schneider, respectively. The authors wish to thank the National Council of Scientific and Technical Research (CONICET) for its support, Engineer Armando Junquera (Asociación Cooperativas Argentinas) for the ACA 901 wheat seeds, and Dr. Mónica Ricci (School of Agronomic and Forest Sciences, National University of la Plata, UNLP) for the R. padi clones to initiate our aphid colonies. We are also grateful to Summit-Agro S.A. Argentina, BASF, Argentina, and Gleba, Argentina, for providing samples of insecticides. Dr. Donald F. Haggerty, a retired academic career investigator and native English speaker, edited the final version of the manuscript. We are very grateful to the two anonymous reviewers and Editor, whose contributions have helped to improve the manuscript.

\section{References}

Agostini MG, Natale GS, Ronco AE (2010) Lethal and sublethal effects of cypermethrin to Hypsiboas pulchellus tadpoles. Ecotoxicology 19:1545-1550

Almeida-Sarmento R, Pallini A, Venzon M, Fonseca de Souza OF, Molina-Rugama AJ, Lima de Oliveira CL (2007) Functional response of the predator Eriopis connexa (Coleoptera: Coccinellidae) to different prey types. Braz Arch Biol Technol 50: $121-126$

Bacci L, Crespo ALB, Galvan TL, Pereira EJG, Picanco MC, Silva GA, Chediak M (2007) Toxicity of insecticides to the sweetpotato whitefly (Hemiptera: Aleyrodidae) and its natural enemies. Pest Manag Sci 63:699-706

Benamú MA, Schneider MI, Gonzalez A, Sánchez NE (2013) Short and long-term effects of three neurotoxic insecticides on the orb-web spider Alpaida veniliae (Araneae, Araneidae): implications for IPM programs. Ecotoxicology 22:1155-1164

Biddinger DJ, Weber DC, Hull LA (2009) Coccinellidae as predators of mites: Stethorini in biological control. Biol Control 51:268-283

Biondi A, Desneux N, Siscaro G, Zappalà L (2012) Using organiccertified rather than synthetic pesticides may not be safer for biological control agents: selectivity and side effects of 14 pesticides on the predator Orius laevigatus. Chemosphere 87:803-812

Blacquiêre T, Smagghe G, Cornelis van Gestel CAM, Mommaerts M (2012) Neonicotinoids in bees: a review on concentrations, sideeffects and risk assessment. Ecotoxicology 21:973-992

Cámara Argentina de Sanidad Agropecuaria y Fertilizantes: Guía de productos fitosanitarios (2013/2015) CASAFE, Buenos Aires, Argentina

Cappello VY, Fortunato N (2008) Dirección Provincial de Recursos Naturales, Programa de Gestión Ambiental en Agroecosistemas. Plaguicidas en la Provincia de Buenos Aires: informacioón 
toxicológica, ecotoxicológica y aspectos ambientales. Organismo Provincial para el Desarrollo Sustentable, pp 1-146

Chagnon M, Kreutzweiser D, Mitchell EAD, Morrissey CA, Noome DA, van der Sluijs JP (2015) Risks of large-scale use of systemic insecticides to ecosystem functioning and services. Environ Sci Pollut Res 22:119-134

Chen TY, Liu TX (2002) Susceptibility of immature stages of Chrysoperla rufilabris (Neurop., Chrysopidae) to pyriproxyfen, a juvenile hormone analog. J Appl Entomol 126:125-129

Cock MJW, van Lenteren JC, Brodeur J, Barratt BIP, Bigler F, Bolckmans K, Cônsoli FL, Haas F, Mason PG, Parra JRP (2010) Do new access and benefit sharing procedures under the convention on biological diversity threaten the future of biological control? BioControl 55(19):9-218

Darvas B, Polgar LA (1998) Novel type insecticides: specificity and effects on non-target organisms. In: Ishaaya I, Degheele D (eds) Insecticides with novel modes of action. Springer, Berlin, pp 188259

Desneux N, Pham-Delegue MH, Kaiser L (2004a) Effects of sublethal and lethal doses of lambda-cyhalothrin on oviposition experience and host searching behaviour of a parasitic wasp, Aphidius ervi. Pest Manag Sci 60:381-389

Desneux N, Rafalimanana H, Kaiser L (2004b) Dose-response relationship in lethal and behavioural effects of different insecticides on the parasitic wasp Aphidius ervi. Chemosphere 54:619-627

Desneux N, Fauvergue X, Dechaume-Moncharmont FX, Kerhoas L, Ballanger Y, Kaiser L (2005) Diaeretiella rapae limits Myzus persicae populations following applications of deltamethrin in oilseed rape. J Econ Entomol 98:9-17

Desneux N, Decourtye A, Delpuech JM (2007) The sublethal effects of pesticides on beneficial arthropods. Annu Rev Entomol 52:81-106

Duarte Gómez W, Zenner de Polanía I (2009) Tabla de vida del cucarrón depredador Eriopis connexa (Germar). Revista U.D.C.A. Actualidad Divulgación Científica 12:147-155

Environmental Protection Agency (EPA) (2013) http://www.epa.org. Accessed 27 July 2013

Fogel MN (2012) Selectividad de insecticidas utilizados en cultivos hortícolas del Cinturón Hortícola Platense sobre el depredador Eriopis connexa en el marco del Manejo Integrado de Plagas. Tesis Doctoral, Facultad de Ciencias Exactas, Universidad Nacional de La Plata, 146 pp

Fogel MN, Schneider MI, Desneux N, Gonzalez B, Ronco AE (2013) Impact of the neonicotinoid acetamiprid on immature stages of the predator Eriopis connexa (Coleoptera: Coccinellidae). Ecotoxicology 22:1063-1071

Garzon A, Medina P, Amor F, Vinuela E, Budia F (2015) Toxicity and sublethal effects of six insecticides to last instar larvae and adults of the biocontrol agents Chrysoperla carnea (Stephens) (Neuroptera: Chrysopidae) and Adalia bipunctata (L.) (Coleoptera: Coccinellidae). Chemosphere 132:87-93

Ghanim M, Ishaaya I (2010) Insecticides with novel modes of action: mechanism and resistance management. In: Ishaaya I, Degheele D (eds) Insecticides with novel modes of action: mechanism and application. Springer, Berlin, pp 385-407

Gibbs KE, Mackey RL, Currie DJ (2009) Human land use, agriculture, pesticides and losses of imperiled species. Divers Distrib 15:242253

Grafton-Cardwell EE, Gu P (2003) Conserving vedalia beetle, Rodolia cardinalis (Mulsant) (Coleoptera: Coccinellidae) in citrus: a continuing challenge as new insecticides gain registration. J Econ Entomol 96:1388-1398

He YX, Zhao J, Zheng Y, Zhan Z, Desneux N, Wu KM (2012) Lethal effect of imidacloprid on the coccinellid predator Serangium japonicum and sublethal effects on predator voracity and on functional response to the whitefly Bemisia tabaci. Ecotoxicology 21: $1291-1300$
Ishaaya A, De Cock A, Degheele D (1994) Pyriproxyfen, a potent suppressor of egg hatch and adult formation of the greenhouse whitefly (Homoptera: Aleyrodidae). J Econ Entomol 87:1185-1189

Ishaaya I, Kontsedalov S, Masirov D, Horowitz AR (2001) Biorational agents - mechanism, selectivity and importance in IPM programs for controlling agricultural pests. Med Landbouww Rijksuniv Gent $66: 363-374$

Ishaaya I, Barazani A, Kontsedalov S, Horowitz AR (2007) Insecticides with novel modes of action: mechanism, selectivity and cross-resistance. Entomol Res 37:148-152

Jacas J, Urbaneja A (2009) Origen de las plagas e historia del Control Biológico. In: Jacas J, Urbaneja A (eds) Control Biológico de Plagas Agrícolas. Phytoma, España, pp 3-13

James DG (2004) Effect of buprofezin on survival of immature stages of Harmonia axyridis, Stethorus punctum picipes (Coleoptera: Coccinellidae), Orius tristicolor (Hemiptera: Anthocoridae), and Geocoris spp. (Hemiptera: Geocoridae). J Econ Entomol 97:900 904

Kim DS, Brooks DJ, Riedl H (2006) Lethal and sublethal effects of abamectin, spinosad, methoxyfenozide and acetamiprid on the predaceous plant bug Deraeocoris brevis in the laboratory. Biocontrol 51:65-484

Liu T-X, Stansly PA (2004) Lethal and sublethal effects of two insect growth regulators on adult Delphastus catalinae (Coleoptera: Coccinellidae), a predator of whiteflies (Homoptera: Aleyrodidae). Biol Control 30:298-305

Lorca Gonzalez RM (2005) Toxicidad de insecticidas sobre Eriopis connexa (Germar) (Coleoptera: Coccinellidae). Universidad de Chile, Facultad de Ciencias Agronómicas, Escuela de Agronomía. Memoria de título, Santiago, Chile

Malagnoux L, Capowiez Y, Rault M (2015) Impact of insecticide exposure on the predation activity of the european earwig Forficula auricularia. Environ Sci Pollut Res 22:14116-14126

Martos A, Niemeyer HM (1990) Dos estudios sobre crianza masal del coccinélido Eriopis connexa Germar. Rev Per Entomol 32:50-52

Medina P, Budia F, Del Estal P, Adan A, Viñuela E (2003) Side effects of six insecticides on different developmental stages of Chrysoperla carnea (Neuroptera: Chrysopidae). IOBC/ wprs Pestic Benefic Org Bull 25:33-40

Mendel Z, Blumberg D, Ishaaya I (1994) Effects of some insect growth regulators on natural enemies of scale insects (Hom.: Coccoidea). Entomophaga 39:199-209

Mestdagh I, De Clercq P, Degheele D (1996) Suceptibility of the predatory bug Podisus maculiventris Say (Heteroptera: Pentatomide) to pyriproxyfen residues on sweet pepper plants. Parasitica 52:153161

Michaud JP (2012) Coccinellids in biological control. In: Hodek HF, Honĕk A (eds) Ecology and behaviour of the Ladybird Beetles (Coccinellidae). Wiley-Blackwell Publishing Ltd., UK, pp 488-490

Mohaghegh J, De Clercq P, Tirry L (2000) Toxicity of selected insecticides to the spined soldier bug, Podisus maculiventris (Heteroptera: Pentatomidae). Biocontrol Sci Tech 10:33-40

Moscardini VF, Da Costa Gontijo P, Carvalho GA, Lopes de Oliveira R, Jader Braga M, Silva FF (2013) Toxicity and sublethal effects of seven insecticides to eggs of the flower bug Orius insidiosus (Say) (Hemiptera: Anthocoridae). Chemosphere 92:490-496

Moser SE, Obrycki JJ (2009) Non-target effects of neonicotinoid seed treatments; mortality of coccinellid larvae related to zoophytophagy. Biol Control 51:487-492

Obrycki JJ, Harwood JD, Kring TJ, O’Neil RJ (2009) Aphidophagy by Coccinellidae: application of biological control in agroecosystems. Biol Control 51:244-254

Papachristos D, Milonas P (2008) Adverse effects of soil applied insecticides on the predatory coccinellid Hippodamia undecimnotata (Coleoptera: Coccinellidae). Biol Control 47:77-81 
Planes L, Catalán J, Tena A, Porcuna JL, Jacas JA, Izquierdo J, Urbaneja A (2013) Lethal and sublethal effects of spirotetramat on the mealybug destroyer, Cryptolaemus montrouzieri. J Pest Sci 86:321-327

Rill SM, Grafton-Cardwell EE, Morse JG (2008) Effects of two insect growth regulators and a neonicotinoid on various life stages of Aphytis melinus (Hymenoptera: Aphelinidae). Biocontrol 53:579-587

Rimoldi F, Schneider MI, Ronco AE (2008) Susceptibility of Chrysoperla externa (Neuroptera: Chrysopidae) to conventional and biorational insecticides. Environ Entomol 37:1252-1257

Rimoldi F, Schneider MI, Ronco AE (2012) Short and Long-term effects of endosulfan, cypermethrin, spinosad, and methoxyfenozide on adults of Chrysoperla externa (Neuroptera: Chrysopidae). J Econ Entomol 105:1982-1987

Ronco AE, Carriquiriborde P, Natale GS, Martin ML, Mugni H, Bonetto C (2008) Integrated approach for the assessment of biotech soybean pesticides impact on low order stream ecosystems of the Pampasic Region. In: Chenand J, Guo C (eds) Ecosystem ecology research. Nova, Hauppauge, pp 209-239

Sánchez-Bayo F (2011) Impacts of agricultural pesticides on terrestrial ecosystems. In: Sánchez-Bayo F, van den Brink PJ, Reinier RM (eds) Ecological impacts of toxic chemicals. Bentham Science Publishers Ltd, pp 63-87

Schneider MI, Smagghe G, Gobbi A, Viñuela E (2003) Toxicity and pharmacokinetics of seven novel insecticides on pupae of Hyposoter didymator (Hymenoptera: Ichneumonidae), a parasitoid of early larval instars of lepidopteran pests. J Econ Entomol 96: 1054-1065

Schneider MI, Smagghe G, Pineda S, Viñuela E (2004) Action of insect growth regulator insecticides and spinosad on life history parameters and absorption in third instar larvae of the endoparasitoid Hyposoter didymator. Biol Control 31:189-198

Schneider MI, Pineda S, Smagghe G (2006) Side effects of conventional and non-conventional insecticides on eggs and larvae of Chrysoperla externa (Hagen) (Neuroptera: Chrysopidae) in Argentine. Commun Appl Biol Sci 71:425-427

Singh PB, Singh V (2008) Cypermethrin induced histological changes in gonadotrophic cells, liver, gonads, plasma levels of estradiol 17-_ and 11-ketotestosterone, and sperm motility in Heteropneustes fossilis (Bloch). Chemosphere 72:422-431

Stark JD, Vargas R, Banks JE (2007) Incorporating ecologically relevant measures of pesticide effect for estimating the compatibility of pesticides and biocontrol agents. J Econ Entomol 100:1027-1032

Stenersen J (2004) Chemical pesticides: mode of action and toxicology. CRC Publisher, New York

Tomizawa M, Casida JE (2005) Neonicotinoid insecticide toxicology: mechanisms of selective action. Annu Rev Pharmacol Toxicol 45: 247-268

Viñuela E, Medina MP, Schneider MI, Gonzalez M, Budia F, Adán A, Del Estal P (2001) Comparison of side-effects of spinosad, tebufenozide and azadirachtin on predators Chrysoperla carnea and Podisus maculiventris and the parasitoids Opius concolor and Hyposoter didymator under laboratory conditions. IOBC WPRS Bull 24:25-34

Ware G, Whitacre D (2004) The pesticide book, 6th edn. MeisterPro, USA

Weber DC, Lundgren JG (2009) Assessing the trophic ecology of the Coccinellidae: their roles as predators and as prey. Biol Control 51:199-214

Wyckhuys KAG, Lu Y, Morales H, Vazquez LL, Legaspi JC, Eliopoulos PA, Hernandez LM (2013) Current status and potential of conservation biological control for agriculture in the developing world. Biol Control 65:152-167

Yao F-L, Zheng Y, Zhaoa J-W, Desneux N, Hea Y-X, Weng Q-Y (2015) Lethal and sublethal effects of thiamethoxam on the whitefly predator Serangium japonicum (Coleoptera: Coccinellidae) through different exposure routes

Youn YN, Seo MJ, Shin JG, Jang C, Yub YM (2003) Toxicity of greenhouse pesticides to multicolored Asian lady beetles, Harmonia axyridis (Coleoptera: Coccinellidae). Biol Control 28:164-170

Yu C, Lin R, Fu M, Zhou Y, Zong F, Jiang H, Lv N, Piao X, Zhang J, Liu Y, Brock TCM (2014) Impact of imidacloprid on life-cycle development of Coccinella septempunctata in laboratory microcosms. Ecotoxicol Environ Saf 110:168-173

Zar JH (1996) Biostatistical analysis. Prentice Hall, New Jersey 